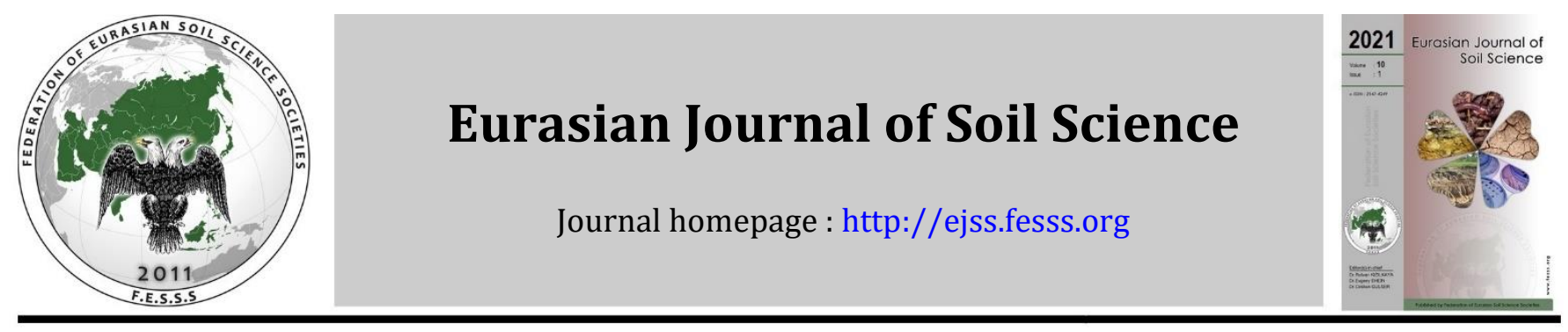

\title{
Soil organic matter composition of forest Rendzinas in West Bulgaria
}

\author{
Biser Hristov a,b,*, Ivaylo Kirilov b, Pavel Pavlov a
}

a University of Forestry, $10 \mathrm{Kl}$. Ohridski Blvd., Sofia 1797, Bulgaria

b N. Poushkarov Institute of Soil Science, Agrotechnologies and Plant Protection, Sofia, Bulgaria

\section{Article Info}

Received : 24.02.2021

Accepted : 29.06.2021

Available online : 05.07.2021

\section{Author(s) \\ B. Hristov * \\ I. Kirilov \\ P. Pavlov}

* Corresponding author

\begin{abstract}
The paper deals with of the relations between the forest ecosystem, calcareous rocks and content and composition of soil organic matter in the Golo Bardo area in West Bulgaria. In that area Rendzinas are used mainly for forestry, viticulture and pastures. A specific study based on the accumulation of soil organic matter according to the data on the composition of the soil organic acids. The research on the soil organic matter composition provided information on the course of the humification processes in studied soils. Soil organic matter accumulation in Rendzinas depends on different factors, such as land use and climatic conditions. Soil has rapid transformations of organic residues and strongly decomposed plant tissue predominates. There are often signs of active work of the soil mesofauna. Studied soils have good reserves of organic carbon high degree of humification. The organic carbon content varies in a wide range from 0.8 to $7.2 \%$. The humic acids prevail over fulvic acids, and the degree of humification is higher in deeper horizons. According to the $\mathrm{C} / \mathrm{N}$ ratio the humus type is Mull in almost all horizons. Studied soils are biologically active that have favorable impact over the soil structure and vegetation. Rendzinas have high potential of organic carbon sequestration.
\end{abstract}

Keywords: Fulvic acids, humic acids, Rendzina, soil organic matter.

(C) 2021 Federation of Eurasian Soil Science Societies. All rights reserved

\section{Introduction}

Golo Bardo is located in Western Bulgaria, between the Pernik and the Radomir valleys. It is a small undivided, oblong mountain with steep slopes and a broad flat ridge with afforested areas. Accoding to Belivanova (1997) the mountain is built up by Triassic sediments, which usually are limestones and dolomites. Its highest peak is Vetrushka (1158 m a.s.l.). On the slopes of Ostritsa Peak there is a reserve of the same name, one of the oldest, designed to protect rare species of grass and shrubs.

The soil cover of in the area were studied for the first time by Koynov (1943), he mentioned about redbrown humus-carbonate soils over limestone at the foot of Golo Bardo mountain. Such soils are spread in foothills and mountain areas in the same region. The main soil type of the region is Rendzina that could be classified as Rendzic Leptosol or Rendzic Phaeozem according to IUSS Working Group (2015) soil classification system, but also in that area could be found Leptosols, shallow Phaeozems and Cambisols. These soils are mainly under forest. In many places deep soil could turn into shallow Rendzinas deeper up to 20-30 cm due to soil erosion. These soils are typical for the region of Pernik district and near the town of Radomir in Western Bulgaria. Calcareous soils are spread over $12 \%$ of soil resources in the world (FAO, 1996).

https://doi.org/10.18393/ejss.962542

http://ejss.fesss.org/10.18393/ejss.962542 e-ISSN : 2147-4249 
Rendzians formation and distribution is mainly related to the mineral composition and chemical of the calcareous rock, as well as to its physical, chemical and mineral properties (Donov, 1993; Artinova 2014; Bogdanov et al.; 2015, Filcheva and Malinova 2015; Filcheva and Sarafov 2015; Ilinkin et al., 2017).

The average content of soil organic matter (SOM) in the surface horizon of uncultivated soils in lowland and mountainous areas is from 5 to $7 \%$ up to $13.5 \%$ at above $800 \mathrm{~m}$ a.s.l. Differences in organic matter content are determined mainly by the altitude and vegatatopn cover (Bachvarova et al., 2005). Schreier and Lavkulich (1985) mentioned that these soils are with polygenetic origin. They have developed under conditions where humic acid accumulation is greater than decomposition as a result of the limestone-rich environment, and where a portion of the organic component might be derived from residues of bedrock weathering.

Carbonate content varies over a wide range (10-50\%). To be classified as Rendzinas soil forming materials should contain more than $40 \%$ carbonates. Rendzinas are soils with high sorption capacity and the soil reaction is neutral and slightly alkaline from 7 to $8.4 \mathrm{pH}$ in water. The high calcium content could have negative affect over nutrient assimilation. It is necessary to improve the nutrient content in the soils to meet the requirements for vegetation (Ilinkin et al., 2017). The use of humus-carbonate soils for cultivation of agricultural crops leads to changes only in humus content and humus reserves, especially in the orchard (Filcheva, 2007).

According Shishkov and Kolev (2014) the organic matter content and composition of Rednzinas has an advanced stage of humification. The SOM content is between 4 to $10 \%$ in uncultivated land and it is less in arable land. Humus is entirely composed of humic acids bounded with calcium. The C/N ratio is about 8-12 and indicates humus enrichment with nitrogen. Rendzina soil characteristics (total $\mathrm{N}$ content and humus fractional composition) are very important because they are closely related to soil-forming factors and processes (Radmanovic et al., 2020).
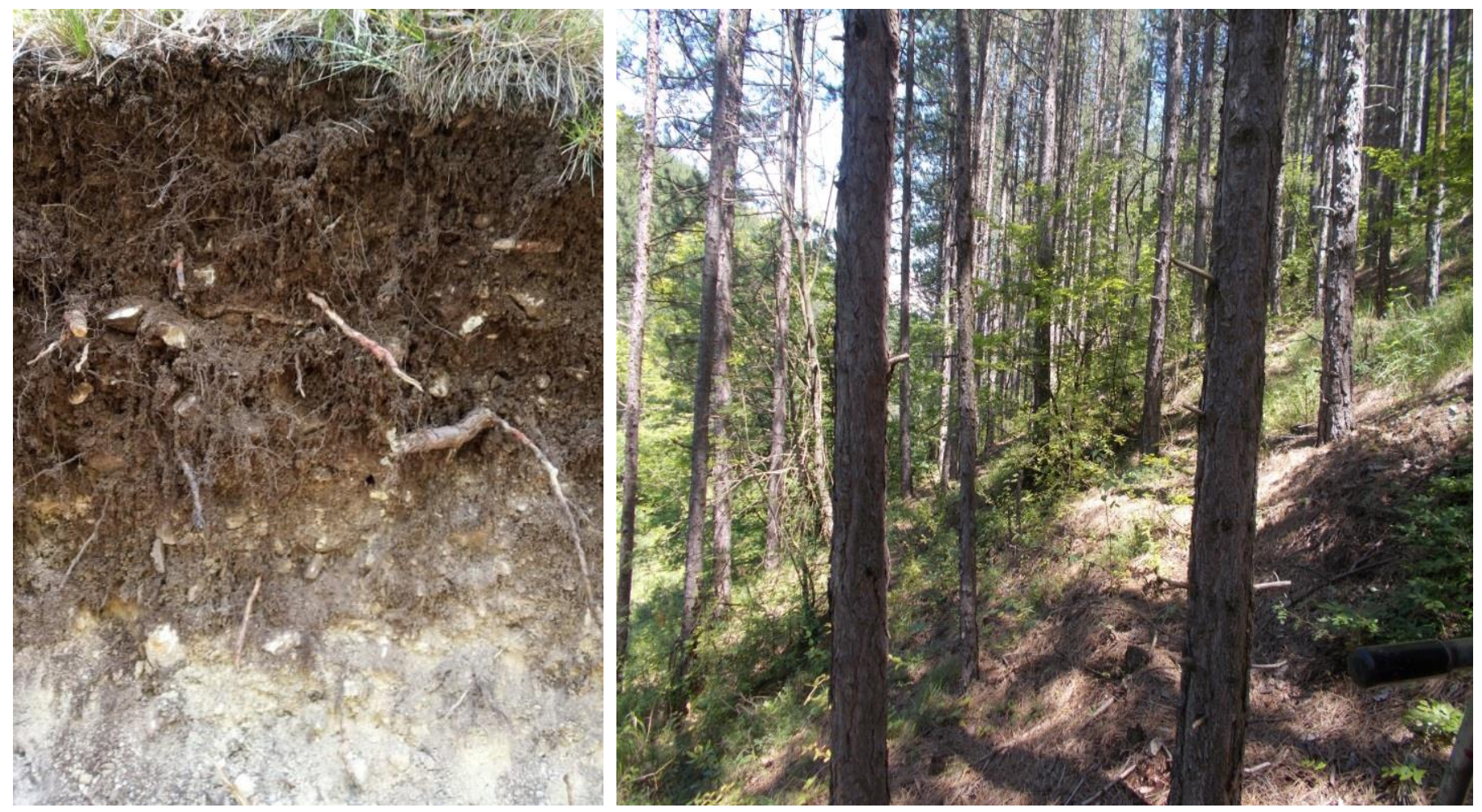

Figure 1. Typical soil profile of Rendzina, under Black pine forest.

The aim of this study is to analyze soil organic matter content and composition, as well as the factors of humus formation in the Golo Bardo Mountain, in order to facilitate the planning and implementation of activities related to preserve soil organic carbon stocks. 


\section{Material and Methods}

\section{Description of the study area}

The study area is Golo Bardo Mountain, which is located at $25 \mathrm{~km}$ south west direction from the city of Sofia, the capital of Bulgaria (Figure 2). The mountain covers from northwest to southeast area about $25 \mathrm{~km}$ long and its width is 6-7 km. Its slopes gradually sink into the Pernik and Radomir valleys. On the west side Struma River separates it from the Cherna Gora Mountain. The upper side reaches the Struma River again from side of Vitosha Mountain.

The Golo Bardo Mountain has average altitude about $1000-1100 \mathrm{~m}$, and its slopes are slightly sloping, deforested and furrowed by ravines. The mountains rocks are usually Triassic limestone, dolomite and marl. The surface and underground karst has a massive development, and many karst springs could be found. The climate is temperate continental. Almost the entire mountain is drained by small and short tributaries of the Struma River.

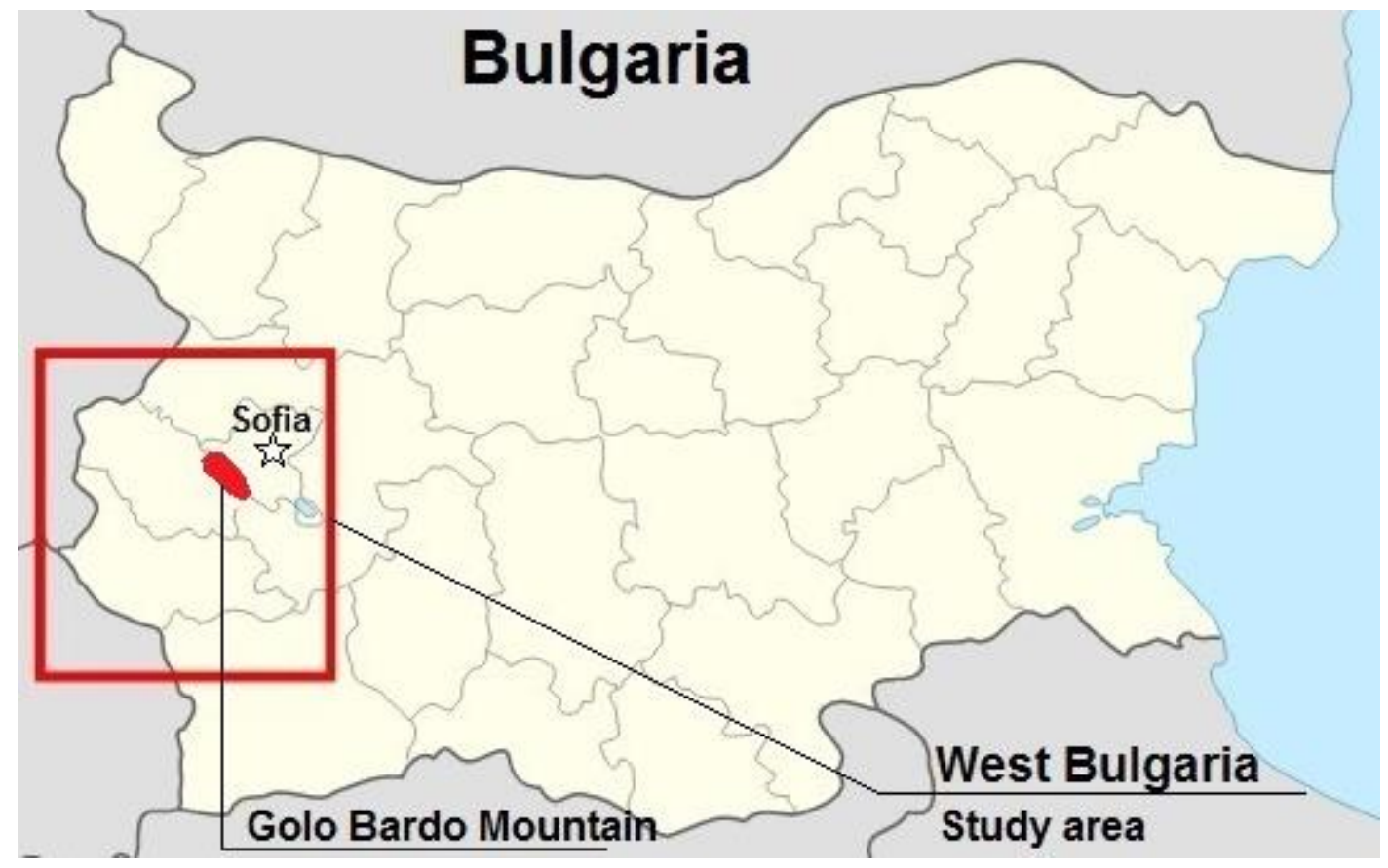

Figure 2. West Bulgaria and Golo Bardo Mountain, study area

\section{Soil analysis}

Eight soil profiles were morphologically described and 26 soil samples were analysed. Bulgarian soil classification defines them as Typical and Skeletic Rendzians (Teoharov, 2019). According IUSS Working Group (2015) classification studied soils are Rendzic Leptosols, Calcaric Leptosol, Rendzic Phaeozems and Endocalcic Phaeozems. Soil organic matter composition was determined by the method of KononovaBelchikova (Kononova, 1966; Filcheva and Tsadilas, 2002; Hristova et al., 2016; Filcheva et al., 2018). For total nitrogen is used Kjeldahl method (Arinushkina, 1961). Microsoft Excel 2017 is used for graphics and statistics.

\section{Results and Discussion}

Studied Rendzinas are usually shallow soils with A-AC-CR profile, well-formed humus layer with good fine granular structure to crumb structure with different content of rock fragments in the profile. Soil texture of Rendzinas are mainly sandy-clay, sandy-loam, silty loam with different contents of the biger particals of limestone. Soils are with loose structure, warm and well-aerated soils. A considerable part of them have an unfavorable water regime due to their shallow profile. In many places soil cover is cut by rocks.

Under the natural vegetation, predominantly forest and pastures, in which the studied soils are formed accumulate significant quantities of humus with favorable composition and properties (Table 1). In the complex processes of transformation of plant residues into soil organic matter, it may turn out that in addition to the possibility of differences in the properties of the litter of one species, some fractions of debris undergo certain changes in some circumstances and different changes (Handley, 1954). 
Table 1. Content and composition of soil organic matter

\begin{tabular}{|c|c|c|c|c|c|c|c|c|c|c|c|c|c|c|c|c|}
\hline \multirow{2}{*}{$\begin{array}{c}\text { Soil } \\
\text { profile }\end{array}$} & \multirow{2}{*}{$\begin{array}{c}\text { Soil horizon } \\
\text { depth, cm }\end{array}$} & \multirow{2}{*}{$\begin{array}{c}\text { Total C, } \\
\%\end{array}$} & \multicolumn{3}{|c|}{$\begin{array}{c}\text { Organic carbon, \% } \\
\text { Extracted with } \\
0.1 \mathrm{M} \mathrm{Na} \mathrm{P}_{2} \mathrm{O}_{7}+0.1 \mathrm{M} \mathrm{NaOH}\end{array}$} & \multirow[t]{2}{*}{$\mathrm{Ch} / \mathrm{Cf}$} & \multicolumn{2}{|c|}{$\begin{array}{l}\text { Organic carbon, } \% \\
\text { Fractions of humic } \\
\text { acids, } \%\end{array}$} & \multirow{2}{*}{ 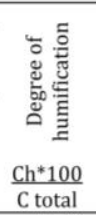 } & \multirow{2}{*}{ 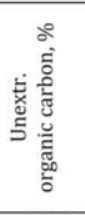 } & \multirow{2}{*}{ 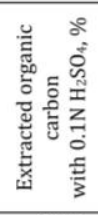 } & \multicolumn{2}{|c|}{$\begin{array}{c}\text { Optic } \\
\text { characteristics } \\
\left(\mathrm{E}_{4} / \mathrm{E}_{6}\right) \\
\end{array}$} & \multirow{2}{*}{ 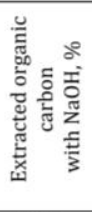 } & \multirow[t]{2}{*}{$\begin{array}{l}\text { Total } \\
\mathrm{N}, \%\end{array}$} & \multirow{2}{*}{$\mathrm{C} / \mathrm{N}$} \\
\hline & & & $\begin{array}{c}\text { Total C, } \\
\%\end{array}$ & $\begin{array}{c}\text { Humic } \\
\text { acids, \%, }\end{array}$ & $\begin{array}{c}\text { Fulvic } \\
\text { acids, \% }\end{array}$ & & $\begin{array}{l}\text { Free or } \\
\text { bound with } \\
\mathrm{R}_{2} \mathrm{O}_{3}, \%\end{array}$ & $\begin{array}{c}\text { Bound } \\
\text { with } \mathrm{Ca}^{2+} \text {, } \\
\%\end{array}$ & & & & $\begin{array}{l}\text { Total } \\
\text { humic } \\
\text { acids }\end{array}$ & $\begin{array}{l}\text { Free } \\
\text { humic } \\
\text { acids }\end{array}$ & & & \\
\hline 1 & Akh 0-5 & 7.14 & 2.52 & 1.37 & 1.15 & 1.19 & 62.04 & 39.96 & 19.19 & 4.62 & 0.09 & 5.86 & 6.73 & 1.63 & 0.407 & 17.54 \\
\hline 1 & Ak 5-20 & 2.53 & 0.78 & 0.41 & 0.37 & 1.11 & 0.00 & 100.00 & 16.21 & 1.75 & 0.06 & 4.47 & - & 0.28 & 0.255 & 9.92 \\
\hline 1 & ACk 20-38 & 1.26 & 1.18 & 0.50 & 0.68 & 0.73 & 66.00 & 34.00 & 39.68 & 0.08 & 0.14 & 4.78 & 5.04 & 0.66 & 0.153 & 8.24 \\
\hline 2 & ACk 0-19 & 5.35 & 1.39 & 0.52 & 0.87 & 0.60 & 78.85 & 21.15 & 9.72 & 3.96 & 0.15 & 4.86 & 2.68 & 0.65 & 0.465 & 11.51 \\
\hline 3 & Ah $0-10$ & 6.00 & 1.43 & 0.63 & 0.80 & 0.89 & 52.38 & 47.62 & 10.50 & 4.57 & 0.12 & 4.57 & 4.60 & 0.70 & 0.598 & 10.03 \\
\hline 3 & A1 $10-22$ & 3.40 & 1.06 & 0.52 & 0.54 & 0.96 & 36.54 & 63.46 & 15.29 & 2.34 & 0.00 & 4.33 & 4.07 & 0.40 & 0.407 & 8.35 \\
\hline 3 & ACk $22-43$ & 2.89 & 0.57 & 0.45 & 0.12 & 3.75 & 0.00 & 100.00 & 15.57 & 2.32 & 0.05 & 4.04 & - & 0.27 & 0.354 & 8.16 \\
\hline 3 & Ck1 43-60 & 1.97 & 0.57 & 0.26 & 0.31 & 0.84 & 0.00 & 100.00 & 13.20 & 1.40 & 0.05 & 2.78 & - & 0.19 & 0.235 & 8.38 \\
\hline 3 & Ck2 60-100 & 1.14 & 0.32 & 0.19 & 0.13 & 1.46 & 0.00 & 100.00 & 16.67 & 0.82 & 0.03 & 4.03 & - & 0.11 & 0.119 & 9.58 \\
\hline 4 & Ah $0-10$ & 7.80 & 2.27 & 1.27 & 1.00 & 1.27 & 68.50 & 31.50 & 16.28 & 5.53 & 0.08 & 4.78 & 7.02 & 1.54 & 0.487 & 10.02 \\
\hline 4 & ACk $10-28$ & 4.08 & 1.09 & 0.58 & 0.51 & 1.14 & 32.76 & 67.24 & 14.22 & 2.99 & 0.07 & 3.96 & 7.15 & 0.39 & 0.385 & 10.6 \\
\hline 4 & CRk 28-70 & 2.86 & 0.84 & 0.52 & 0.32 & 1.63 & 30.77 & 69.23 & 18.18 & 2.02 & 0.06 & 4.11 & 2.96 & 0.26 & 0.349 & 8.19 \\
\hline 6 & $A_{k} 15-30$ & 1.85 & 0.47 & 0.30 & 0.17 & 1.76 & 0.00 & 100.00 & 16.22 & 1.38 & 0.08 & 4.14 & - & 0.22 & 0.196 & 9.44 \\
\hline 6 & $\mathrm{AC}_{\mathrm{k}} 230-50$ & 2.09 & 0.52 & 0.33 & 0.19 & 1.74 & 0.00 & 100.00 & 15.79 & 1.57 & 0.09 & 4.32 & - & 0.23 & 0.211 & 9.90 \\
\hline 6 & $\mathrm{AC}_{\mathrm{k}} 50-80$ & 1.13 & 0.30 & 0.18 & 0.12 & 1.50 & 0.00 & 100.00 & 15.93 & 0.83 & 0.06 & 3.63 & - & 0.16 & 0.137 & 8.25 \\
\hline 7 & Akh 0-9 & 6.63 & 1.82 & 1.02 & 0.80 & 1.28 & 34.41 & 65.69 & 15.38 & 4.81 & 0.21 & 4.31 & 4.46 & 0.73 & 0.522 & 12.70 \\
\hline 7 & Ak 9-32 & 4.20 & 1.15 & 0.84 & 0.31 & 2.71 & 0.00 & 100.00 & 20.00 & 3.05 & 0.16 & 3.95 & - & 0.30 & 0.394 & 10.66 \\
\hline 7 & ACk1 32-45 & 3.29 & 1.04 & 0.71 & 0.33 & 2.15 & 0.00 & 100.00 & 21.58 & 2.25 & 0.11 & 3.93 & - & 0.20 & 0.336 & 9.79 \\
\hline 7 & ACk2 45-61 & 2.86 & 0.92 & 0.63 & 0.29 & 2.17 & 0.00 & 100.00 & 22.03 & 1.94 & 0.09 & 3.87 & - & 0.17 & 0.292 & 9.79 \\
\hline 7 & Ck1 61-90 & 2.36 & 0.70 & 0.50 & 0.20 & 2.50 & 0.00 & 100.00 & 21.19 & 1.66 & 0.09 & 3.83 & - & 0.12 & 0.236 & 10.00 \\
\hline 7 & Ck2 90-120 & 2.09 & 0.74 & 0.47 & 0.27 & 1.74 & 0.00 & 100.00 & 22.49 & 1.35 & 0.08 & 3.94 & - & 0.16 & 0.214 & 9.77 \\
\hline 8 & Ak $0-11$ & 5.33 & 1.20 & 0.80 & 0.40 & 2.00 & 33.75 & 66.25 & 15.01 & 4.13 & 0.17 & 4.63 & 3.84 & 0.45 & 0.511 & 10.43 \\
\hline 8 & ACk $11-30$ & 3.52 & 0.73 & 0.45 & 0.28 & 1.61 & 0.00 & 100.00 & 12.78 & 2.79 & 0.09 & 4.32 & - & 0.23 & 0.374 & 9.41 \\
\hline
\end{tabular}

The soil-forming effect of the place where the organic residues decompose and the particle size composition of the soils control the rate of decomposition and humification of the organic residues.

These processes of plant residues decaying and mineralization of the constituent elements are an important issue for the carbon cycle. Dead plants and leaves are the primary items to degrade the processes in the surface horizon. In the forests above the limestone, the litter is subsequently incorporated into the deep soil by earthworms (Scheu and Wolters, 1991).

Visual observation shows that in these soils rapid transformations of organic residues and strongly decomposed plant tissue predominate. There are often signs of active work of the soil mesofauna. Humus is dark-coloured, according to Munsell Color (1994) is ususally with values - 10YR 3/3; 10YR 3/4 which is drak olive brown and olive brown. The surface horizon contains carbonates, its reaction is neutral or slightly alkaline. Surface soil horizons are naturally active soils that contain high amount of stable forms of organic compounds which favorably affects the soil structure and plant vegetation.

Rendzinas have well-formed humus horizon and humus accumulation is up to a depth of $50 \mathrm{~cm}$. The distribution of organic matter usually is decreasing in depth. The organic carbon content is the highest in the surface of the humus-accumulative horizon. Depending on the conditions of humification and the participation of vegetation, organic carbon content varies in quite wide range and reaches 5-7.2\% (Table 1 and Figure 3) In rich carbonate soil-forming materials it is less than $0.5 \%$ (Ck horizon). The average content of organic carbon is $3.4 \%$ in whole profile (Table 2). Organic content classification of Gurov and Artinova (2004) shows that studied Rendzinas have very high amount of humus content. Similarly, as in the case of other soils, the organic carbon stock as well as accumulation of organic matter in different forms in Rendzinas depend on many factors, such as land use, vegetation and climatic conditions.

An important factor forming the sequestration of carbon in calcareous soils is the type of parent rock, which determines the content of calcium and magnesium and the amount and type of clay minerals. All the processes described above lead to the creation of specific morphological properties of Rendzinas with a deep black surface horizon, as well as certain conditions - and specific feature of organic compounds (Wasak et al., 2018).

The type of humus is fulvic-humic to humic, the ratio $\mathrm{Ch} / \mathrm{Cf}$ is from 0.6 to 3.75 (Figure 4). The degree of humification is high in the almost all soil horizons (10-22\%). Humic acids in deepest part of soil profile are bound to calcium and the degree of condensation of the aromatic nuclei is high (E2:E6 3-6), the involvement of the aggressive fraction of fulvic-acids is insignificant - 5-7 \%. 


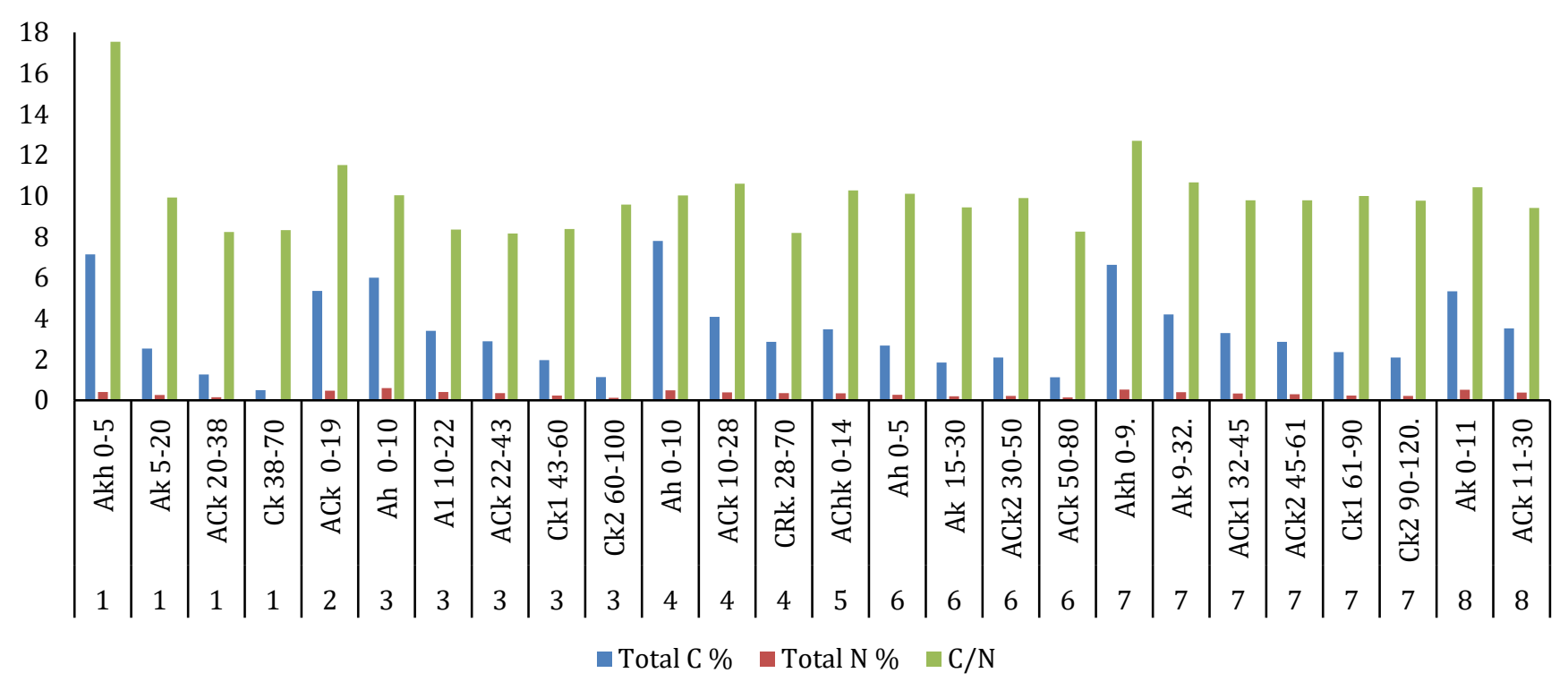

Figure 3. Total organic carbon (C, \%), total nitrogen $(\mathrm{N}, \%)$ and ratio $\mathrm{C} / \mathrm{N}$

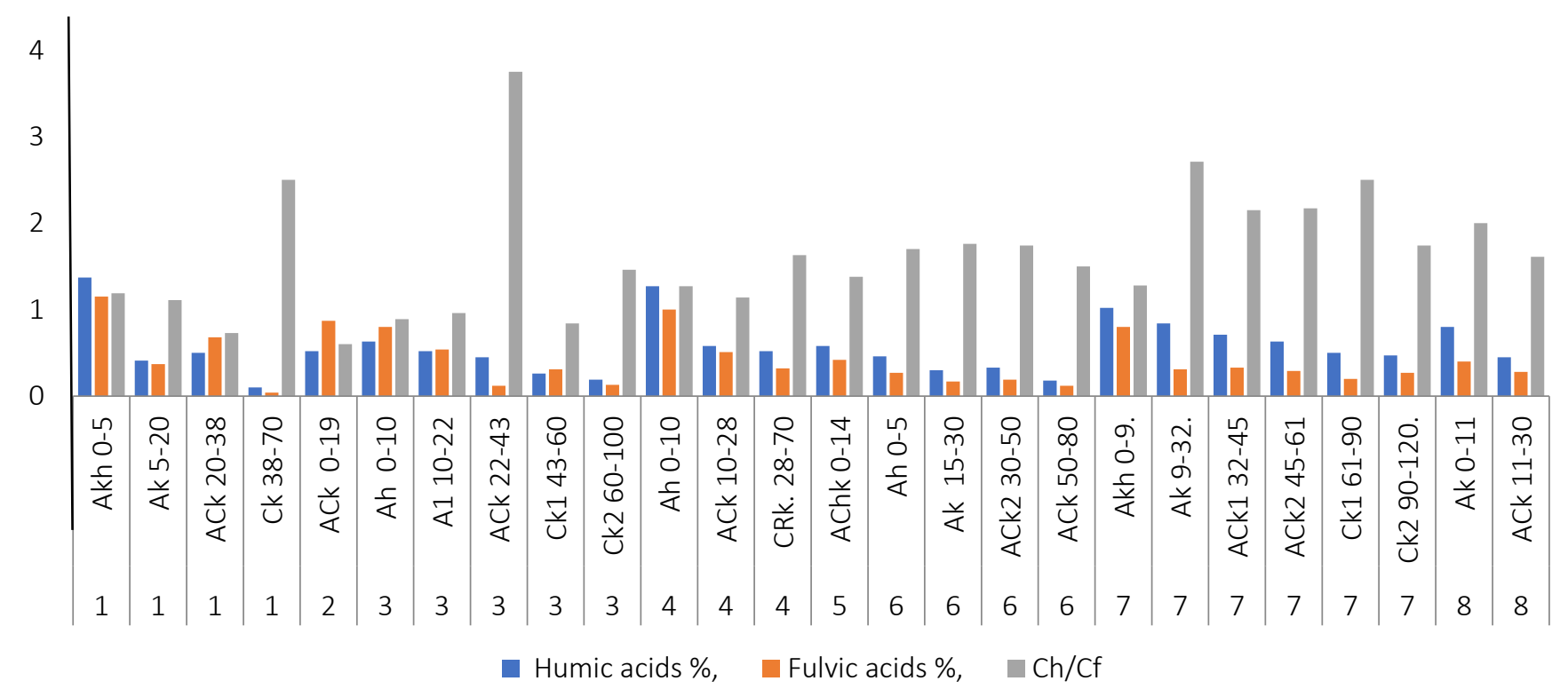

Figure 4. Extracted humic and fulvic acids (\%), and ratio humic acid/fulvic acids (Ch/Cf)

According to Kononova (1966), the humus is 'Second type' and it is typical for Phaeozems, Rendzinas, Chernozems and Kastanozems. humic/fulvic (Ch/Cf) acid ratio is upper than 1. Extent of aromatic nuclei condensation is high in humic acids, which cause their hydrophobic properties and inability to creation of chelates. Unusually favoralble humic acids are strongly bounded with mineral components of soil in this type of humus.

In most cases the soil horizons humic acids are $100 \%$ bounded with calcium. In some surface horizons, humic acids are free or bound with sesquioxide $\mathrm{R}_{2} \mathrm{O}_{3}$. The reason for that is surface litter of plant residues in which calcium is insufficient and fulvic acids are much more.

In all soil horizons (except in profile 1 ) the type of humus according C:N ratio is Mull $(<14)$. This type of ratio is specific characteristic for forests, or grasslands with temperate climate. The porous, crumbly humus rapidly decomposes and becomes well mixed into the mineral soil, so that distinct layers are not apparent. Where free $\mathrm{CaCO}_{3}$ occurred in the Ah-horizon, a mull forest horizon had developed even on coarse sand and the associated herb flora differed only slightly from that occurring on very acid mull. 
According to Delecour (1980), the mull type of humus generally form under trees with more nutrient-rich litter, where gut-passage through soil animals followed by predominantly bacterial decomposition creates granular structures

Table 2. Descriptive statistics of soil organic matter content.

\begin{tabular}{lcccccc}
\hline & Total C, $\%$ & Total N, \% & C/N & Extract Humic acids, $\%$ & Extract Fulvic acids, \% & Ch/Cf \\
\hline Mean & 3.40 & 0.32 & 9.98 & 0.56 & 0.42 & 1.63 \\
Standard Error & 0.38 & 0.03 & 0.37 & 0.06 & 0.06 & 0.14 \\
Median & 2.88 & 0.34 & 9.85 & 0.51 & 0.32 & 1.56 \\
Mode & 2.86 & 0.41 & 9.79 & 0.52 & 0.80 & 2.50 \\
Standard Deviation & 1.93 & 0.14 & 1.89 & 0.30 & 0.29 & 0.71 \\
Sample Variance & 3.74 & 0.02 & 3.58 & 0.09 & 0.09 & 0.50 \\
Range & 7.30 & 0.54 & 9.38 & 1.27 & 1.11 & 3.15 \\
Minimum & 0.50 & 0.06 & 8.16 & 0.10 & 0.04 & 0.60 \\
Maximum & 7.80 & 0.60 & 17.54 & 1.37 & 1.15 & 3.75 \\
\hline
\end{tabular}

The correlation matrix in table 3 shows very good relation between main soil organic matter values. There are very high positive correlation (0.90), between total organic carbon and total nitrogen content, that's explain the mull type of humus, the high enrichment of soil organic matter with nitrogen. Extracted humic and fulvic acids also have good correlation with organic carbon and nitrogen.

Table 3. Correlation between main soil organic matter values.

\begin{tabular}{|c|c|c|c|c|c|}
\hline & Total C & Ex. Humic acids, , & Ex. Fulvic acids & Humification & Total N \\
\hline Total C, & $*$ & & & & \\
\hline Ex. Humic acids, & 0.89 & * & & & \\
\hline Ex. Fulvic acids, & 0.84 & 0.79 & $*$ & & \\
\hline Humification & -0.35 & 0.03 & -0.04 & * & \\
\hline Total N & 0.90 & 0.71 & 0.67 & -0.45 & \\
\hline
\end{tabular}

*In bold: positive correlation between values

\section{Conclusion}

Studied soils, mainly Rendzinas, have shallow profile over weathered calcareous rock with high number of skeletal fragments, and well-formed dark colored surface rich of humus horizon. The amount of soil organic carbon in the surface horizon is high, up to $7.8 \%$. The average content of organic carbon is $3.4 \%$ in whole profile. The type of humus is humic to humic-fulvic-, and the ratio $\mathrm{Ch} / \mathrm{Cf}$ is from 0.6 to 3.75. The degree of humification is high in the almost all horizons. Humic acids are predominantly bounded with calcium and optical properties are with high density. In some surface horizons, humic acids are free or bound with sesquioxide, because of organic litter of plant residues in the surface. According C:N ratio the type of humus is mull (under 15), in all soil horizons, except one. Enrichment of soil organic matter with nitrogen is high, that is proved also with high correlation between total organic carbon and total nitrogen content. .

Studied soils are biological active with high amount of stable forms of humus and that have favorable impact over the soil structure and vegetation. Rendzinas have high potential of organic carbon sequestration.

\section{References}

Arinushkina, E.V., 1961. Chemical soil analysis guide. Ed. Moscow State University. 151 p.

Artinova, N., 2014. Humus status of soils in Bulgaria. In: Soil Organic Matter and Fertility of Soils in Bulgaria. Bulgarian Humic Substances Society. pp. 29-74 [in Bulgarian].

Belivanova, V., 1997. Diagenesis of the Triassic carbonate rocks from the Golo Bardo Mountain, Southwestern Bulgaria. Geologica Balcanica 27(1-2): 27-35.

Bogdanov, S., Savev, S., Tsavkov, E., 2015. Investigation on humus-carbonate soils in the Western Balkan Mountains foothill. Environmental Engineering and Environmental Protection 15(3): 29-35. [in Bulgarian].

Bachvarova, S., Georgiev, B., Teoharov, M., Samlieva, A., Krasteva, V., 2005. Southwestern Agrotechpark In: Assessment of the agro-ecological potential on the territory of the agro-parks in the country optimizing the structure of agricultural production, Scientific works of NACAN. 2: 315 - 351. p. [in Bulgarian].

Delecour, F., 1980. Essai de classification pratique des humus. Pedologie 30: 225-241. 
Donov, V., 1993. Forest soil science. Martilen publishing pouse. 430 p. [in Bulgarian].

FAO 1996. Digital soil map of the world and derived soil properties (Version 3.5). Food and Agriculture Organization of the United Nations (FAO), Rome, Italy.

Filcheva, E., 2007. Characteristics of the soils of Bulgaria according content and composition of soil organic matter. In: Grouping of soils in Bulgaria. Minerva Publishing, Bulgaria. 191 p. [in Bulgarian].

Filcheva E., Hristova M., Nikolova P., Popova T., Chakalov K., Savov V., 2018. Quantitative and qualitative characterisation of humic products with spectral parameters. Journal of Soils and Sediments 18: 2863-2867.

Filcheva E.G., Tsadilas C.D.. 2002. Influence of clinoptilolite and compost on soil properties. Communications in Soil Science and Plant Analysis 33(3-4): 595-607.

Filcheva E., Sarafov A. 2015. Characteristics of Soil Humus Systems, Formed on Metacarbonate Rocks of Dobrostan Formation. Soil Science Agrochemistry and Ecology 49(1): 3-12 [in Bulgarian].

Filcheva E., Malinova L. 2015. Composition of soil organic matter in Eutric Cambisols developed on marble. Soil science, Agrochemistry and Ecology 49(4): 8-12 [in Bulgarian].

Gurov G., Artinova N. 2004. Soil Sceince. Macros-2001. Plovdiv. 474 p. [in Bulgarian].

Handley, W.R.C., 1954. Mull and mor formation in relation to forest soils. Forestry Commission Bulletin 23, London. 132p.Available at [access date:24.02.2021]: https://www.forestresearch.gov.uk/documents/6489/FCBU023.pdf

Hristova, M., Filcheva, E., Nikolova, P., 2016. Reliability of the method for determination of soil organic carbon. $4^{\text {th }}$ National Conference Bulgarian Humic Substances Society, 8-10 September 2016, Sofia, Bulgaria. pp.318-327 [in Bulgarian].

Ilinkin, V., Bogdanov, S., Goleva, A., 2017. Characteristics of Rendzinas in the Ludogorie Region. Bulgarian Journal of Soil Science 2(1): 32-41.

Koynov V. 1943. Soil of Radomir district. Yearbook of Bulgarian Academy of Science, book XL-2. [in Bulgarian].

Kononova, M.M., 1966. Soil organic matter: Its nature, its role in soil formation and in soil fertility. 2nd Edition. Pergamon Press Ltd, Oxford, London, UK. 543p.

Munsell Color, 1994. Munsell Soil Color Charts, 1994 Revised edition. New Windsor, New York, USA. 29p.

IUSS Working Group, 2015. World Reference Base for Soil Resources WRB 2014, update 2015. International soil classification system for naming soils and creating legends for soil maps. World Soil Resources Reports No. 106. Food and Agriculture Organization of the United Nations (FAO), Rome, Italy. 192p. Available at [access date: 24.02.2021]: http://www.fao.org/3/i3794en/I3794en.pdf

Radmanovic, S.B., Gajic-Kvascev, M.D., Mrvic, V.V., Dordevic, A.R., 2020. Characteristics of Rendzina soils in Serbia and their WRB classification. Journal of Agricultural Sciences (Belgrade) 65(3): 251-261.

Scheu, S., Wolters, V., 1991. Influence of fragmentation and bioturbation on the decomposition of 14C-labelled beech leaf litter. Soil Biology and Biochemistry 23(1): 1029-1034.

Schreier, H., Lavkulich L.M., 1985. Rendzina - type soils in the Ogilvie mountains, Yukon territory. Soil Science 139(1): 2-12.

Shishkov, T., Kolev, N., 2014. The Soils of Bulgaria, Springer. 208p.

Teoharov, M., 2019. Rendzinas. In: Genetic and Applied Classifications of Soils and Lands in Bulgaria. 214p. [in Bulgarian].

Wasak, K., Drewnik, M., 2018. Sequestration of organic carbon in rendzinas - a review. Soil Science Annual 69(2): 75-87. 